SACRED CONSUMPTION 
THIS PAGE INTENTIONALLY LEFT BLANK 


\section{SACRED CONSUMPTION}

FOOD and RITUAL in

AZTEC ART and CULTURE

ELIZABETH MORÁN

UNIVERSITY OF TEXAS PRESS

Austin 


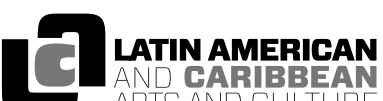 \\ ARTS AND CULTURE}

This book is a part of the Latin American and Caribbean Arts and Culture publication initiative, funded by a grant from the Andrew W. Mellon Foundation.

Copyright (C) 2016 by the University of Texas Press

All rights reserved

Printed in the United States of America

First edition, 2016

Requests for permission to reproduce material

from this work should be sent to:

Permissions

University of Texas Press

P.O. Box 7819

Austin, TX 78713-7819

http://utpress.utexas.edu/index.php/rp-form

(a) The paper used in this book meets the minimum requirements of ANSI/NISO Z39.48-1992 (R1997) (Permanence of Paper).

LIBRARY OF CONGRESS CATALOGING-IN-PUBLICATION DATA

Names: Morán, Elizabeth, Ph.D., author.

Title: Sacred consumption : food and ritual in Aztec art and culture / Elizabeth Morán.

Description: First edition. | Austin : University of Texas Press, 2016. |

Series: Latin American and Caribbean arts and culture publication initiative (Andrew W. Mellon foundation) | Includes bibliographical references and index. | Description based on print version record and CIP data provided by publisher; resource not viewed.

Identifiers: LCCN 2015043235 (print) | LCCN 2015044243 (e-book)

ISBN 9781477310595 (cloth : alk. paper)

ISBN 9781477310694 (pbk. : alk. paper)

ISBN 9781477310700 (library e-book)

ISBN 9781477310717 (non-library e-book)

Subjects: LCSH: Aztecs-Food. | Food in art. | Food-Social aspects-Mexico. | Aztec art-Themes, motives. | Aztecs-

Social life and customs. | Art, Mexican-History.

Classification: LCC F1219.76.F67 (print) |

LCC F1219.76.F67 M67 2016 (e-book)

DDC 394.1/20972-dc23

LC record available at http://lccn.loc.gov/2015043235

doi: $10.7560 / 310595$ 
To Mayra, for her endless knowledge and willingness to always share it 
THIS PAGE INTENTIONALLY LEFT BLANK 